JIAFE (Jurnal Ilmiah Akuntansi Fakultas Ekonomi) https://journal.unpak.ac.id/index.php/jiafe
Vol. 7 No. 2, Des 2021, Hal. 175-186

P-ISSN: 2502-3020, E-ISSN: 2502-4159

\title{
KEBIJAKAN PEMBAGIAN DIVIDEN KAS DI PERUSAHAAN SUB SEKTOR PERDAGANGAN ECERAN
}

\author{
Rochman Marota ${ }^{1}$, Vinna Oktaviani ${ }^{2}$, dan Amelia Rahmi ${ }^{3}$ \\ 1,2,3 Universitas Pakuan, Bogor, Indonesia \\ Email korespondensi: ${ }^{2}$ oktavianivinna@gmail.com
}

\begin{abstract}
ABSTRAK
Tujuan dari penelitian ini adalah untuk menganalisis pengaruh laba bersih, arus kas operasi, investment opportunity set, dan firm size terhadap dividen kas. Penelitian ini dilakukan pada perusahaan sub perdagangan eceran yang terdaftar di Bursa Efek Indonesia periode 2015-2019. Sampel terdiri dari lima perusahaan yang dipilih dengan menggunakan metode purposive sampling. Penelitian ini menggunakan uji regresi linear berganda untuk menguji hipotesis. Hasil pengujian menunjukkan bahwa laba bersih berpengaruh positif terhadap dividen kas, sedangkan arus kas operasi, investment opportunity set, dan firm size tidak berpengaruh. Hal ini dapat menjadi perhatian bagi perusahaan untuk terus meningkatkan kinerja perusahaan dalam menghasilkan laba bersih. Dengan laba yang tinggi, para investor akan lebih tertarik untuk menginvestasikan dananya.
\end{abstract}

Kata kunci: arus kas operasi; dividen kas; firm size; investment opportunity set; laba bersih

\section{ABSTRACT}

The purpose of this study is to analyze the effect of net income, operating cash flow, investment opportunity set, and firm size on cash dividends. This research was conducted on sub-retail trading companies listed on the Indonesia Stock Exchange for the 2015-2019 period. The sample consists of five companies, selected using the purposive sampling method. It uses multiple linear regression to test the hypotheses. Results show that net income affects positively cash dividends. While cash flow, investment opportunity set, and firm size does not affect cash dividends. This can be a concern for the company to continue to improve the company's performance in generating net income. With high profits, investors will be more interested in investing their funds.

Keywords: cash dividend; firm size; investment opportunuty set; net income; operating cash flow

\section{KETERANGAN ARTIKEL}

Riwayat Artikel: diterima: 30 Agustus 2021; direvisi: 16 Desember 2021; disetujui: 21 Desember 2021

Klasifikasi JEL: G31

Cara mensitasi: Marota, R., Oktaviani, V., Rahmi, A. (2021). Kebijakan Pembagian Deviden Kas di Perusahaan Sub-Sektor Perdagangan Eceran. JIAFE (Jurnal Ilmiah Akuntansi Fakultas Ekonomi), 7(2), 175-186. https://doi.org/10.34204/jiafe.v7i2.3800

\section{PENDAHULUAN}

Keputusan perusahaan untuk menahan atau mendistribusikan labanya kepada pemegang saham disebut kebijakan dividen. Kebijakan pembagian dividen mempunyai dampak yang sangat penting bagi investor maupun perusahaan. Dividen penting bagi pemegang saham karena menjadi sinyal kondisi keuangan perusahaan. Perusahaan yang membayar dividen secara stabil akan dipandang negatif ketika adanya penurunan atau penghentian dividen. Begitu juga dengan perusahaan yang ang tidak pernah membayar dividen akan dipandang baik ketika mereka akan membayar dividen (Rehman \& Takumi, 2012). Secara 
Rochman Marota: Kebijakan Pembagian Dividen ...

umum investor lebih menyukai dividen daripada capital gain, dibandingkan dengan capital gain, dividen memiliki risiko yang lebih rendah dan kepastian yang lebih tinggi daripada mengandalkan pada perubahan harga saham (Marina, dkk., 2020). Investor umumnya lebih suka dividen tunai yang relatif stabil karena mengurangi ketidakpastian aktivitas investasi (Supeni, 2020).

Ada banyak faktor yang diduga mempengaruhi pembagian dividen kas pada perusahaan. Faktor yang utama adalah laba bersih. Menurut Rudianto (2018) laba adalah selisih antara penghasilan yang dihasilkan perusahaan dari pelanggan atas penjualan barang atau jasa yang dihasilkannya dan pengeluaran yang dilakukan perusahaan untuk mendapatkan barang atau jasa tersebut. Laba bersih dihasilkan perusahaan dari pendapatan di kurang beban-beban. Jika laba bersih perusahaan besar, maka manajemen perusahaan dapat dengan leluasa menentukan besarnya dividen yang akan dibagikan kepada pemegang saham. Dividen yang dibayarkan kepada pemegang saham berasal dari laba bersih periode berjalan atau tahun sebelumnya. Pernyataan tersebut sejalan dengan penelitian yang dilakukan oleh Wenas dkk. (2017) yang menyimpulkan bahwa laba bersih secara parsial dan simultan berpengaruh positif terhadap dividen kas. Begitu juga dengan Wijaya dkk. (2016), dan Febrinal (2016). Sedangkan Kharisma \& Tobing (2020) menyatakan laba bersih berpengaruh negatif terhadap kebijakan dividen.

Selain informasi laba, faktor lain yang diduga menjadi dasar pengambilan keputusan pembagian dividen kas adalah arus kas operasi. Menurut Kartikahadi, dkk. (2012) para pemangku kepentingan bukan saja perlu mengetahui apakah suatu entitas mampu menghasilkan laba, tetapi juga perlu mengetahui apakah kegiatan operasi entitas mampu menghasilkan arus kas positif, artinya penerimaan operasi melampaui pengeluaran operasi. Arus kas dari aktivitas operasi perusahaan merupakan indikator bagaimana perusahaan mengelola kas yang ada untuk melunasi pinjaman, memelihara kemampuan operasi perusahaan, membayar dividen, dan melakukan investasi baru tanpa mengandalkan sumber pendanaan eksternal (Rudianto, 2018). Menurut Wenas, dkk. (2017) sumber kas dari aktivitas operasi pada umumnya dinilai sebagai alat ukur terbaik untuk mengukur kemampuan perusahaan dalam menghasilkan kas dalam rangka mendukung keberlangsungan perusahaan. Pernyataan tersebut sejalan dengan penelitian yang dilakukan oleh Purba dkk. (2017) arus kas operasi berpengaruh positif terhadap kebijakan dividen, sedangkan hasil penelitian Febrinal (2016) menyatakan bahwa arus kas operasi tidak berpengaruh terhadap kebijakan dividen.

Ketersediaan investasi masa depan atau yang lebih dikenal dengan Investment Opportunity Set (IOS) dinilai sebagai salah satu faktor yang mempengaruhi kebijakan dividen perusahaan. Investment opportunity set adalah suatu alternatif atau komitmen mengenai peluang investasi dimasa yang akan datang bagi suatu perusahaan (Steven, 2018). Menurut Prihatmiko, dkk. (2012) investment opportunity set dapat menurunkan dividen perusahaan karena para manajemen perusahaan lebih termotivasi untuk mendanai investasi yang akan dilakukan oleh perusahaan melalui pendanaan internal dibandingkan pendanaan eksternal. Terdapat hubungan terbalik antara besarnya investasi dengan rasio pembayaran dividen dalam hal ini dividen kas. Penelitian yang dilakukan oleh Andaswari, dkk. (2017) menyatakan bahwa Investment Opportunity Set berpengaruh positif terhadap kebijakan dividen, sedangkan Purba, dkk. (2017) dalam penelitiannya menyatakan bahwa investment opportunity set tidak berpengaruh.

Ukuran perusahaan (firm size) menjadi faktor lain dan tidak kalah penting yang diduga mempengaruhi kebijakan pembagian dividen kas. Ukuran perusahaan yang besar akan memiliki keuntungan yang lebih sehingga akan berdampak pada kebijakan dividen. Sebuah perusahaan besar biasanya memiliki akses yang lebih baik ke modal pasar dan merasa lebih mudah untuk mengumpulkan dana dengan biaya lebih rendah dan kendala lebih sedikit dibandingkan dengan perusahaan kecil. Oleh karena itu, perusahaan besar lebih cenderung membayar dividen yang lebih tinggi kepada pemegang saham (Lestari, 2018). Perusahaan yang sudah mapan, yang berarti tidak memiliki rencana pengembangan usaha, umumnya akan membagikan dividen tunai yang lebih tinggi dan perusahaan yang 
JIAFE (Jurnal Ilmiah Akuntansi Fakultas Ekonomi) https://journal.unpak.ac.id/index.php/jiafe
Vol. 7 No. 2, Des 2021, Hal. 175-186

P-ISSN: 2502-3020, E-ISSN: 2502-4159

sedang berkembang umumnya akan membagikan dividen yang lebih rendah (Samsul, 2015). Berdasarkan penelitian Atmoko dkk. (2017) ukuran perusahaan berpengaruh positif terhadap dividen payout ratio, sedangkan menurut Fahriyani (2016) firm size tidak berpengaruh terhadap kebijakan dividen.

Berdasarkan pernyataan di atas maka peneliti tertarik untuk melakukan penelitian kebijakan pembagian dividen kas pada perusahaan sub sektor perdagangan eceran yang terdaftar di bursa efek Indonesia periode 2015-2019. Walaupun banyak penelitian terkait kebijakan pembayaran dividen yang telah dilakukan, masih banyak inkonsistensi serta kebijakan pembagian dividen mempunyai dampak yang sangat penting bagi investor maupun perusahaan, sehingga masih menjadi topik yang banyak diperbincangkan sehingga menarik untuk diteliti. Penelitian yang akan peneliti lakukan menggunakan variabel independen yang masing-masing dihitung menggunakan indikator laba bersih diproksikan dengan Earning Per Share (EPS), arus kas operasi diproksikan dengan Cash Flow Return on Stockholders Equity (CFRSER), investment opportunity set (IOS) diproksikan dengan Market to Book Value of Equity (MBVE), Firm Size diproksikan dengan size dan variabel dependen dividen kas diproksikan dengan Dividend Payout Ratio (DPR).

Unit analisis dalam penelitian ini adalah perusahaan perdagangan eceran yang terdaftar di BEI. Hal ini bertujuan untuk bisa membandingkan besarnya kinerja masing-masing perusahaan karena terdapat persaingan yang ketat di antara perusahaan perdagangan eceran yang terdaftar di BEI.

Pemilihan periode penelitian dengan periode selama lima tahun yaitu tahun 2015-2019. Menurut Hendartyo (2017), mengutip pendapat Ketua Umum Asosiasi Pengusaha Ritel Indonesia (Aprindo) Roy Nicholas Mandey, mengatakan sejak 2015 bisnis ritel di Indonesia mengalami performa di bawah normal.

Dengan demikian, tujuan penelitian ini adalah untuk menganalisis pengaruh laba bersih yang diukur dengan earning per share, arus kas operasi yang diukur dengan cash flow return on stockholders equity ratio, bahwa investment opportunity set yang diukur dengan market to book value of equity dan firm size yang diukur dengan size terhadap dividen kas pada perusahaan sub sektor perdagangan eceran yang terdaftar di BEl periode 2015-2019.

\section{KAJIAN LITERATUR DAN PENGEMBANGAN HIPOTESIS} Teori Keagenan (Agency Theory)

Jensen dan Meckling (1976) menjelaskan bahwa teori keagenan mendeskripsikan pemegang saham sebagai prinsipal dan manajemen sebagai agen. Hubungan ini tidak selalu harmonis, dalam hal ini pemegang saham dan manajemen mempunyai kepentingan yang berbeda. Tujuan dari pemegang saham adalah untuk mendapat keuntungan dalam bentuk dividen sedangkan manajemen bertujuan untuk membuat perusahaannya makin maju dan berkembang dengan memanfaatkan laba yang didapat perusahaan untuk investasi. Pada dasarnya tujuan semua perusahaan adalah untuk memaksimalkan kekayaan pemegang saham perusahaan. Namun pada kenyataannya tujuan ini sering tidak terlaksana karena adanya masalah keagenan. Teori keagenan ini menyatakan bahwa ketika perusahaan membayar dividen, hal itu meyakinkan pemegang saham bahwa manajer tidak membuang-buang modal pemegang saham secara seenaknya (Steven, 2018).

\section{Dividen Kas}

Warren dkk. (2018) dividen kas (cash dividend) adalah pembagian laba secara tunai kepada para pemegang saham. Untuk membayarkan dividen kas perusahaan harus memenuhi kondisi berikut: (1) jumlah saldo laba (retained earning) yang memadai (2) jumlah kas yang memadai (3) tindakan formal yang dilakukan oleh dewan direksi. Indikator dividen kas mengunakan rasio pembayaran dividen (dividend payout ratio), menetapkan jumlah laba yang dapat ditahan dalam perusahaan, makin banyak jumlah laba 
Rochman Marota: Kebijakan Pembagian Dividen ...

saat ini yang ditahan perusahaan berarti makin sedikit uang yang dialokasikan untuk pembayaran dividen (Home \& Wachowicz, 2017). Sebelum dividen dibaagikan, perusahaan harus mempertimbangkan ketersediaan dana untuk membayar dividen. Jika perusahaan memilih untuk membagikan dividen dalam bentuk tunai/kas, artinya perusahaan memiliki kas dalam jumlah yang cukup.

\section{Laba Bersih Terhadap Dividen Kas}

Rudianto (2018) laba adalah selisih antara penghasilan yang dihasilkan perusahaan dari pelanggan atas penjualan barang atau jasa yang dihasilkannya dan pengeluaran yang dilakukan perusahaan untuk mendapatkan barang atau jasa tersebut. Laba bersih dihasilkan perusahaan dari pendapatan dikurangi beban-beban. Pembayaran dividen dari laba bersih periode berjalan melalui pembayar tunai kepada pemegang saham, mengurangi saldo laba. Keputusan jumlah yang akan dibayarkan perusahaan melalui dividen kepada pemegang saham disebut kebijakan dividen. Penelitian Wenas dkk. (2017) menyimpulkan bahwa laba bersih secara parsial dan simultan berpengaruh positif terhadap dividen kas. Begitu juga dengan Wijaya dkk. (2016) dan Siregar \& Hasanah (2019), sedangkan penelitian yang dilakukan oleh Kharisma \& Tobing (2020) menyatakan bahwa laba bersih tidak berpengaruh terhadap kebijakan dividen.

\section{$\mathbf{H}_{1}$ : laba bersih berpengaruh terhadap dividen kas}

\section{Arus Kas Operasi Terhadap Dividen Kas}

Rudianto (2018) arus kas aktivitas operasi yaitu aktivitas penghasil utama pendapatan perusahaan (principal revenue-producing activities) dan aktivitas lain yang bukan merupakan aktivitas investasi dan aktivitas pendanaan. Arus kas dari aktivitas operasi perusahaan merupakan indikator bagaimana perusahaan mengelola kas yang ada untuk melunasi pinjaman, memelihara kemampuan operasi perusahaan, membayar dividen, dan melakukan investasi baru tanpa mengandalkan sumber pendanaan eksternal (Diana \& Setiawati, 2017). Perusahaan yang mampu memelihara kas yang baik pastinya memiliki kecukupan kas untuk membiayai keperluan internal perusahaan. Oleh karena itu jika perusahaan memiliki arus kas operasi yang rendah dapat mempengaruhi pembayaran dividen kas, begitu pun sebaliknya. Menurut Siregar \& Hasanah (2019) arus kas operasi berpengaruh positif terhadap dividen kas. Begitu juga dengan Wenas dkk. (2017) dan Purba dkk. (2017). Berdasarkan penelitian oleh Wijaya dkk. (2016) arus kas operasi berpengaruh negatif terhadap kebijakan dividen, sedangkan Kharisma \& Tobing (2020) menyatakan arus kas operasi tidak berpengaruh terhadap kebijakan dividen.

\section{$\mathrm{H}_{2}$ : arus kas operasi berpengaruh terhadap dividen kas}

\section{Investment Opportunity Set Terhadap Dividen Kas}

Pamungkas (2017) menyebutkan bahwa investment opportunity set merupakan suatu kombinasi antara aktiva yang dimiliki dan pilihan-pilihan investasi di masa yang akan datang dengan net present value positif. Perusahaan yang memiliki IOS yang tinggi memiliki peluang pertumbuhan yang tinggi pula (Purba dkk., 2017). Investment opportunity set adalah suatu alternatif atau komitmen mengenai peluang investasi dimasa yang akan datang bagi suatu perusahaan (Steven, 2018). Ketersediaan investasi masa depan atau yang lebih dikenal dengan investment opportunity set dinilai sebagai salah satu faktor yang mempengaruhi kebijakan dividen perusahaan. Dalam penelitian Andaswari dkk. (2017) menyatakan bahwa investment opportunity set berpengaruh positif dan signifikan terhadap kebijakan dividen. Purba dkk. (2017) dalam penelitiannya menyatakan bahwa bahwa investment opportunity set tidak berpengaruh positif dan signifikan.

$\mathrm{H}_{3}$ : investment opportunity set berpengaruh terhadap dividen kas 
JIAFE (Jurnal Ilmiah Akuntansi Fakultas Ekonomi) https://journal.unpak.ac.id/index.php/jiafe
Vol. 7 No. 2, Des 2021, Hal. 175-186

P-ISSN: 2502-3020, E-ISSN: 2502-4159

\section{Firm Size Terhadap Dividen Kas}

Ukuran perusahaan dapat dilihat dari total aset yang dimiliki oleh perusahaan. Besarnya ukuran perusahaan mencerminkan bahwa perusahaan mengalami pertumbuhan yang baik, meningkatkan nilai perusahaan (Andaswari dkk., 2019). Firm size merupakan tingkat besar kecilnya aktivitas operasional perusahaan. Makin besar firm size maka makin besar pula dividen yang dibayarkan. Perusahaan besar dengan akses pasar yang lebih baik seharusnya membayar dividen yang tinggi kepada pemegang saham, sehingga ukuran perusahaan dan pembayaran dividen memiliki hubungan positif. Berdasarkan penelitian Atmoko dkk. (2017) ukuran perusahaan berpengaruh positif terhadap dividend payout ratio, sedangkan menurut Fahriyani (2016) firm size tidak berpengaruh terhadap kebijakan dividen.

\section{$\mathrm{H}_{4}$ : firm size berpengaruh terhadap dividen kas}

\section{METODE PENELITIAN}

Tujuan penelitian adalah untuk menganalisa pengaruh variabel independen yaitu laba bersih, arus kas operasi, investment opportunity set dan firm size terhadap dividen kas. Berdasarkan dari tujuan penelitian tersebut maka penelitian ini termasuk jenis penelitian verifikatif. Metode penarikan sampel menggunakan purposive sampling. Purposive sampling adalah teknik non-probability sampling dimana pengambilan sampel didasarkan pada kriteria tertentu, yaitu perusahaan sub sektor perdagangan eceran yang terdaftar dan menerbitkan laporan keuangan tahunan yang telah diaudit BEI periode 2015-2019, yang tidak rugi selama periode penelitian, dan yang membagikan debiden kas secara rutin selama periode penelitian. Sampel yang digunakan dalam penelitian ini sebanyak 25 perusahaan.

Metode analisis data yang digunakan, yaitu uji regresi linier berganda dan uji normalitas. Selain itu, penelitian ini menggunakan uji hipotesis yang meliputi uji koefisien determinasi, uji t, dan uji $F$. Analisis data dilakukan dengan dengan bantuan SPSS (Statistik Package for Social Sciense) versi 25.0 for windows.

\section{HASIL DAN PEMBAHASAN}

\section{Statistika Deskriptif}

Data yang menjadi variabel independen adalah laba bersih diproksikan dengan earning per share, arus kas operasi diproksikan dengan cash flow return on stakeholders equity ratio, investment opportunity set diproksikan dengan market to book value of equity, dan firm size diproksikan dengan size, sedangkan variabel dependen adalah dividen kas yang diproksikan dengan dividend payout ratio.

Tabel 1. Statistika Deskriptif

\begin{tabular}{lrrrrr}
\hline & N & Min & Max & Mean & $\begin{array}{c}\text { Std. } \\
\text { Deviation }\end{array}$ \\
\hline Earning Per Share (Rp) & 25 & 6.210 & 91.300 & 40.671 & 24.014 \\
Cash Flow Return on Stakeholders & 25 & - & 102,900 & 39,379 & 34,605 \\
Equity Ratio (\%) & & 11,750 & & & \\
Market to Book Value of Equity (Rp) & 25 & 0,920 & 6.450 & 3.423 & 1.751 \\
SIZE & 25 & 28,800 & 30,810 & 29,469 & 0,628 \\
Dividend Payout Ratio (\%) & 25 & 13,010 & 66,140 & 37,692 & 14,960 \\
\hline
\end{tabular}

Berdasarkan Tabel 1 dapat dilihat bahwa DPR memiliki nilai terendah sebesar 13,010\% dan tertinggi sebesar $66,140 \%$. Standar deviasi menunjukkan penyebaran data variabel DPR adalah sebesar $14,960 \%$ lebih rendah dari nilai rata-rata sebesar $37,690 \%$. Hal ini menunjukkan data bersifat homogen atau penyebaran data sudah baik. Earning per share (EPS) tertinggi sebesar Rp91.300 dan EPS terendah sebesar 
Rp6.210. Sedangkan nilai rata-rata EPS sebesar Rp40.670 lebih besar dari standar deviasi sebesar Rp24.010 menunjukkan data bersifat homogen, artinya data kurang bervariasi atau penyimpangan rendah. Cash Flow Return on Stakeholders Equity (CFRSER) memiliki rata-rata sebesar 39,380\% dengan nilai CFRSER terendah sebesar $11,750 \%$ dan tertinggi sebesar $102,900 \%$. Serta standar deviasi sebesar $34,600 \%$. Nilai rata-rata lebih besar dari standar deviasi menunjukkan data bersifat homogen. Market to Book Value of Equity (MBVE) tertinggi sebesar Rp6.450 dan terendah sebesar Rp0,92 dengan nilai ratarata sebesar Rp3.420 lebih besar dari nilai standar deviasi sebesar Rp1.750 menunjukkan data bersifat homogen, artinya data kurang bervariasi atau penyimpangan rendah. Size pada perusahaan perdagangan eceran 2015-2019 memiliki nilai tertinggi sebesar 30,810 dan terendah sebesar 28,800. Adapun size ini berkisar antara $28,800-30,810$ dan nilai rata-rata 29,690 serta standar deviasi sebesar 0,623 . Nilai ratarata lebih besar dari standar deviasi menunjukkan data bersifat homogen, berarti data size mempunyai penyimpangan yang rendah.

\section{Uji Normalitas}

Berikut disajikan hasil uji normalitas data penelitian untuk menguji apakah data penelitian berdistribusi normal.

Tabel 2. Hasil Uji Normalitas Kologorov-Smirnov Test

\begin{tabular}{|c|c|c|}
\hline \multirow{2}{*}{\multicolumn{2}{|c|}{$N$}} & Unstandardized Residual \\
\hline & & 25 \\
\hline Normal & Mean & 0,000 \\
\hline Parameters ${ }^{a, b}$ & $\begin{array}{l}\text { Std. } \\
\text { Deviation }\end{array}$ & 10,963 \\
\hline Most & Absolute & 0,127 \\
\hline Extreme & Positive & 0,127 \\
\hline Differences & Negative & $-0,115$ \\
\hline Test Statistic & & 0,127 \\
\hline Asymp. Sig. (2- & led) & $0,200^{c, d}$ \\
\hline
\end{tabular}

Berdasarkan tabel hasil uji normalitas di atas diketahui bahwa Asymp. Sig. (2-tailed) adalah 0,200 sehingga menunjukkan data tersebut normal dan memenuhi syarat uji normalitas, karena syarat data yang berdistribusi normal memiliki nilai sig. $>0,050$.

\section{Regresi Linear Berganda}

Berikut disajikan tabel hasil uji regresi linier berganda. Berdasarkan tabel 3 diketahui bahwa variabel EPS (Earning Per Share) proksi dari laba bersih memiliki pengaruh positif dan signifikan terhadap dividen kas yang dibuktikan dengan nilai Sig. 0,001 <0,050. Berbeda dengan EPS, CFRSER (Cash Flow Return on Stakeholders Equity Ratio) proksi dari arus kas operasi tidak berpengaruh terhadap dividen kas karena nilai Sig. 0,158 >0,050. Variabel investment opportunity set yang diproksikan dengan MBVE (Market to Book Value of Equity) memiiki nilai Sig. 0,120 > 0,050 menunjukan bahwa tidak ada pengaruh yang signifikan. Sedangkan variabel Firm Size memiliki nilai Sig. 0,150>0,050 menunjukkan firm size tidak berpengaruh terhadap dividen kas. 
Tabel 3. Hasil Regresi Linear Berganda

\begin{tabular}{|c|c|c|c|c|c|}
\hline \multicolumn{6}{|c|}{ Coefficients $^{\mathrm{a}}$} \\
\hline & \multicolumn{2}{|c|}{$\begin{array}{l}\text { Unstandardized } \\
\text { Coefficients }\end{array}$} & \multirow{2}{*}{$\begin{array}{c}\text { Standardized Coefficients } \\
\text { Beta }\end{array}$} & \multirow[t]{2}{*}{$\mathbf{t}$} & \multirow[t]{2}{*}{ Sig. } \\
\hline & B & $\begin{array}{l}\text { Std. } \\
\text { Error }\end{array}$ & & & \\
\hline (Constant) & $-224,047$ & 159,377 & & $-1,406$ & 0,175 \\
\hline EPS & 0,452 & 0,122 & 0,725 & 3,718 & 0,001 \\
\hline CFRSER & $-0,121$ & 0,082 & $-0,280$ & $-1,466$ & 0,158 \\
\hline MBVE & 2,627 & 1,616 & 0,307 & 1,626 & 0,120 \\
\hline SIZE & 8,115 & 5,425 & 0,340 & 1,496 & 0,150 \\
\hline
\end{tabular}

Uji t

Berdasarkan analisis data yang ditunjukkan dalam Tabel 3 diketahui bahwa secara parsial hanya variabel laba bersih berpengaruh terhadap dividen kas artinya hanya hipotesis 1 diterima, sedangkan variabel arus kas operasi, investment opportunity set dan firm size tidak berpengaruh terhadap dividen kas. Hal ini menunjukkan hipotesis 2 , hipotesis 3 , dan hipotesis 4 ditolak.

\section{Uji Koefisien Determinasi $\left(\mathbf{R}^{2}\right)$}

Berdasarkan Tabel 4 menunjukkan nilai adjusted R square sebesar 0,355. Hal ini berarti 35,5\% variabel dividen kas dapat dijelaskan oleh variabel laba bersih, arus kas operasi, investment opportunity set, dan firm size, sedangkan sisanya yaitu 65,5\% dipengaruhi oleh variabel lain di luar penelitian ini.

Tabel 4. Hasil Uji Koefisien Determinasi $\left(\mathbf{R}^{2}\right)$

\begin{tabular}{crrrr}
\hline Model & $\mathbf{R}$ & $\begin{array}{c}\mathbf{R} \\
\text { Square }\end{array}$ & $\begin{array}{c}\text { Model Summary } \\
\text { Adjusted } \mathbf{R} \\
\text { Square }\end{array}$ & Std. Error of the Estimate \\
\hline 1 & $0,680^{\mathrm{a}}$ & 0,463 & 0,355 & 12,009 \\
\hline
\end{tabular}

a. Predictors: (Constant), SIZE, CFRSER, MBVE, EPS

b. Dependent Variable: DPR

\section{Uji F}

Berdasarkan Tabel 5 di atas menunjukkan secara simultan dapat diketahui bahwa keempat variabel independen yaitu laba bersih, arus kas operasi, investment opportunity set, dan firm size secara bersamasama berpengaruh terhadap kebijakan dividen.

Tabel 5. Hasil Uji F

\begin{tabular}{lllllll}
\hline \multirow{2}{*}{ Model } & \multicolumn{5}{c}{ ANOVA $^{\text {a }}$} \\
& Sum & of & Df & Mean Square & F & Sig. \\
\hline 1 & Squares & & & & & \\
\hline & Regression & 2486,082 & 4 & 621,520 & 4,309 & 0,011 \\
& Residual & 2884,778 & 20 & 144,239 & & \\
\cline { 3 - 5 } & Total & 5370,859 & 24 & & & \\
\hline
\end{tabular}


Rochman Marota: Kebijakan Pembagian Dividen ...

\section{PEMBAHASAN}

\section{Pengaruh Laba Bersih Terhadap Dividen Kas}

Berdasarkan pengolahan data yang diperoleh dan disajikan dalam Tabel 3 maka dapat diketahui bahwa adanya pengaruh positif antara laba bersih yang diukur dengan earning per share (EPS) dengan dividen kas pada lima perusahaan sub sektor perdagangan eceran yang dijadikan sampel dalam penelitian ini. Hasil tersebut menunjukkan bahwa laba bersih berpengaruh terhadap dividen kas atau $\mathrm{H}_{1}$ diterima.

Penelitian ini tidak sejalan dengan teori keagenan, artinya manajemen dan pemegang saham memiliki kepentingan yang sama yaitu memperoleh laba. Laba tersebut akan berguna bagi perusahaan yang dikelola oleh manajemen dan bagi pemegang saham, keuntungan tersebut akan memberikan return yang diharapkan yaitu berupa dividen kas. Kesimpulan penelitian ini sesuai dengan penelitian Siregar \& Hasanah (2019) yang menyatakan bahwa laba bersih berpengaruh positif terhadap dividen kas karena jika tingkat laba bersih perusahaan tinggi dari satu periode ke periode berikutnya maka perusahaan tersebut memiliki potensi untuk membagikan sebagian labanya kepada pemegang saham, dan begitu pula sebaliknya. Nilai laba bersih yang tinggi dari satu periode ke periode berikutnya menunjukkan bahwa kinerja perusahaan makin baik. Laba bersih secara tidak langsung telah mencerminkan kinerja perusahaan dalam suatu periode. Namun, penelitian ini bertentangan dengan penelitian Purba (2017) yang menunjukkan laba bersih tidak berpengaruh signifikan terhadap kebijakan dividen.

\section{Pengaruh Arus Kas Operasi Terhadap Dividen Kas}

Berdasarkan pengolahan data yang diperoleh dan disajikan dalam Tabel 3 maka dapat diketahui bahwa tidak terdapat pengaruh antara arus kas operasi dan dividen kas atau $\mathrm{H}_{2}$ ditolak. Hasil penelitian ini menunjukkan bahwa besarnya arus kas operasi menunjukkan perusahaan tidak mampu memberikan dividen yang lebih tinggi bagi investornya. Ini bisa saja terjadi karena arus kas masuk dialokasikan untuk melunasi pinjaman, memelihara kemampuan operasi perusahaan, dan melakukan investasi tanpa mengandalkan sumber pendanaan eksternal sehingga kas tidak mencukupi untuk membayar dividen kas. Perusahaan yang menghasilkan arus kas dari aktivitas operasi positif belum tentu dapat membayar dividen yang tinggi kepada para pemegang sahamnya karena kas tersebut lebih digunakan untuk mengoptimalkan modal perusahaan (Febrinal, 2016). Penelitian ini sejalan dengan Kharisma \& Tobing (2020) yang menyatakan bahwa arus kas operasi tidak berpengaruh terhadap kebijakan dividen.

\section{Pengaruh Investment Opportunity Set Terhadap Dividen Kas}

Berdasarkan pengolahan data yang diperoleh dan disajikan dalam Tabel 3 maka dapat diketahui bahwa variabel investment opportunity set menunjukkan hasil yang tidak berpengaruh terhadap dividen kas. Dengan demikian dapat dikatakan bahwa $\mathrm{H}_{3}$ ditolak. Ketika kinerja suatu perusahaan dalam kondisi yang sangat baik perusahaan pihak manajemen akan cenderung lebih memilih investasi baru daripada membayar dividen yang tinggi, sehingga dana yang seharusnya digunakan untuk membayar dividen kas kepada pemegang saham justru digunakan untuk investasi. Sebaliknya perusahaan yang mengalami pertumbuhan lambat cenderung membagikan dividen lebih tinggi untuk mengatasi masalah overinvestment (Purnami \& Artini, 2016). Hasil penelitian ini tidak sesuai dengan teori yang menyebutkan investment opportunity set berpengaruh terhadap dividen kas. Namun, hasil penelitian sejalan dengan teori keagenan menjelaskan bahwa variabel investment opportunity set ditandai dengan adanya perbedaan kepentingan antara manajemen dengan para pemegang saham. Manajemen suatu perusahaan akan lebih memilih untuk memanfaatkan kesempatan investasi yang dapat memberikan manfaat di masa depan dibandingkan dengan mendistribusikan laba perusahaan dalam bentuk dividen kepada pemegang saham, sedangkan para pemegang saham ingin perusahaan membagikan laba mereka 
dalam bentuk dividen karena dividen merupakan keuntungan yang didapatkan pemegang saham atas ketersediaan menanamkan modal dalam perusahaan tersebut.

Kesimpulan penelitian ini sejalan dengan penelitian Pradana \& Sanjaya (2017) investment opportunity set tidak berpengaruh terhadap kebijakan dividen karena adanya wewenang yang hampir mutlak pada RUPS. Wewenang RUPS membuat para pemegang saham mayoritas memiliki keputusan yang tinggi dalam pengambilan kebijakan sehingga para pemegang saham minoritas hanya dapat mengikuti keputusan tersebut. Namun, penelitian ini tidak sejalan dengan penelitian Andaswari dkk. (2017) yang menyatakan bahwa investment opportunity set berpengaruh positif terhadap kebijakan dividen.

\section{Pengaruh Firm Size Terhadap Dividen Kas}

Berdasarkan pengolahan data yang diperoleh dan disajikan dalam Tabel 3 maka dapat diketahui bahwa Variabel firm size juga menunjukkan hasil yang tidak berpengaruh terhadap dividen kas artinya $\mathrm{H}_{4}$ ditolak. Dengan demikian dapat dikatakan bahwa $\mathrm{H}_{4}$ ditolak. Hal ini menunjukkan bahwa perusahaan dengan skala besar belum tentu membayar dividen yang tinggi, begitu pun dengan perusahaan kecil belum tentu membayar dividen yang rendah. Menurut Lestari (2018) makin besar ukuran perusahaan maka makin besar pula biaya yang dimiliki. Ini akan menyebabkan berkurangnya proporsi dividen yang dibagikan kepada pemegang saham. Hal ini dapat terjadi karena dana yang didapatkan perusahaan dari modal para pemegang saham tidak hanya digunakan untuk membayar dividen tetapi untuk kepentingan operasi perusahaan seperti melunasi pinjaman, membayar gaji pegawai, dan membeli aset untuk mengembangkan usahanya.

Kesimpulan penelitian ini sejalan dengan penelitian Fahriyani (2016) dan Lestari (2018) yang menyatakan bahwa ukuran perusahaan tidak berpengaruh terhadap kebijakan dividen. Hal ini menunjukkan perusahaan lebih berorientasi pada pertumbuhan perusahaannya. Untuk kepentingan internal, tak jarang para manajer akan menahan laba sebagai bentuk untuk mewujudkan pertumbuhan perusahaan yang lebih tinggi lagi ketimbang membagikan laba tersebut kepada para pemegang sahamnya. Namun penelitian ini tidak sejalan dengan penelitian Atmoko dkk. (2017) yang menyatakan bahwa ukuran perusahaan berpengaruh positif terhadap dividend payout ratio.

\section{KESIMPULAN}

Berdasarkan hasil analisis data dan pembahasan yang telah dilakukan mengenai pengaruh laba bersih, arus kas operasi, investment opportunity set dan firm size terhadap dividen kas pada perusahaan sub sektor perdagangan eceran yang terdaftar di BEI periode 2015-2019. Laba bersih berpengaruh positif terhadap dividen kas pada perusahaan sub sektor perdagangan eceran yang terdaftar di BEI periode 20152109, sedangkan Arus kas operasi, investment opportunity set, dan firm size tidak berpengaruh terhadap dividen kas. Laba bersih, arus kas operasi, investment opportunity set dan firm size secara simultan berpengaruh terhadap dividen kas. Hal ini dapat menjadi perhatian bagi perusahaan untuk terus meningkatkan kinerja perusahaan dalam menghasilkan laba bersih. Dengan laba yang tinggi para investor akan lebih tertarik untuk menginvestasikan dananya. Ini pun dapat dijadikan pertimbangan dalam menentukan kebijakan dividen yang tepat untuk manajemen dan keputusan investasi untuk investor yang mengharapkan penerimaan dividen. Untuk penelitian selanjutnya juga disarankan untuk meneliti lebih lanjut mengenai hal-hal yang dapat mempengaruhi dividen kas juga dapat menambahkan variabelvariabel lain yang dapat mempengaruhi dividen kas, seperti likuiditas, leverage, dan profitabilitas. 
Rochman Marota: Kebijakan Pembagian Dividen ...

\section{DAFTAR PUSTAKA}

Andaswari, S., Setyadi, D., Parminto, A., \& Defung, F. (2019). The Company Size as A Moderating Variable For The Effect Of Investment Opportunity Set, Debt Policy, Profitability, Dividend Policy And Ownership Structure On The Value Of Construction Companies Listed On The Indonesia Stock Exchange. International Journal of Scientific and Technology Research, 8(9), 2356-2362.

Andaswari, S., Pitono, H., \& Iskandar, R. (2017). Analysis of Investment Opportunity Set to Construction Companies Registered in IDX. Proceedings of the Mulawarman International Conference on Economics and Business (MICEB 2017), 81-88.

Atmoko, Y., Defung, F., \& Tricahyadinata, I. (2017). Pengaruh Return On Assets, Debt To Equity Ratio, Dan Firm Size Terhadap Dividend Payout Ratio. KINERJA, 14(2), 103-109.

Diana, A., \& Setiawati, F. (2017). Akuntansi Keuangan Menengah Berdasarkan Standar Akuntansi Keuangan Terbaru. Yogyakarta: ANDI.

Fahriyani, I. (2016). Pengaruh Ukuran Perusahaan, Investment Opportunity Set, dan Profitabilitas terhadap Kebijakan Dividen dengan Debt To Equity Ratio dan Kepemilikan Institusional Sebagai Moderating Variable. Jurnal RAK (Riset Akuntansi Keuangan), 1(1), 27-44.

Febrinal, R. D. (2016). Pengaruh Laba Bersih Dan Arus Kas Operasi terhadap Kebijakan Dividen Pada Perusahaan Properti dan Real Estate yang Terdaftar di Bursa Efek Indonesia Tahun 2012-2016. Jurnal Riset Akuntansi dan Bisnis, 16(2).

Hendartyo, M. (2017, Oktober 17). Sejak 2015 Performa Bisnis Ritel di Indonesia Di Bawah Normal. https://bisnis.tempo.co/read/1025407/sejak-2015-performa-bisnis-ritel-di-indonesia-di-bawahnormal/full\&view $=$ ok

Home, J. C. V., \& Wachowicz, J.M. (2017). Prinsip-Prinsip Manjemen Keuangan. Alih Bahasa: Quratul'ain Mubarakah. Edisi 13. Jakarta: Salemba Empat.

Kartikahadi, H., Siregar, S. V., Sinaga, R. U., Syamsul, M. (2012). Akuntansi Keuangan Berdasarkan SAK Berbasis IFRS. Jakarta: Salemba Empat.

Kharisma, P., \& Tobing, V. C. L. (2020). Pengaruh Laba Bersih dan Arus Kas Operasi Terhadap Kebijakan Dividen Perusahaan Manufaktur di Bursa Efek Indonesia. Aksara Public, 4(1), H. 171-183. http://aksarapublic.com/index.php/home/article/view/392

Lestari, H. S. (2018). Determinants Of Corporate Dividend Policy In Indonesia. In IOP Conference Series: Earth and Environmental Science, 106(1).

Marina, D., Hidayat, W., \& Wihadanto, A. (2020). Analisis Faktor-Faktor Yang Memengaruhi Dividend Payout Ratio Pada Saham-Saham Indeks LQ45 Di Bursa Efek Indonesia Tahun 2011-2017. Jurnal Manajemen Dan Keuangan, 9(2), 206-222. https://doi.org/10.33059/jmk.v9i2.2637

Pamungkas, N. (2017). Earning Per Share Dan Investment Opportunity Set Terhadap. Jurnal Analisa Akuntansi dan Perpajakan, 1(1), 34-41.

Pradana, S. W. L., \& Sanjaya, I. P. S. (2017). Dampak Profitabilitas, Aliran Kas Bebas, dan Kesempatan Investasi Terhadap Pembayaran Dividen Perusahaan Perbankan. Jurnal Keuangan dan Perbankan, 21(1), 113-124. https://doi.org/10.26905/jkdp.v21i1.1232

Prihatmiko, C., Prastiti, D. S., \& Astuti, Y. W. (2012). Analisis Pengaruh Investment Opportunity Set Terhadap Kebijakan Deviden (Perusahaan Real Estate yang Listing di Bursa Efek Indonesia 20092011). Universitas Negeri Malang.

Purba, I. L. P., Suzan, L. \& Mahardika, D. P. K. (2017). Pengaruh Laba Bersih, Arus Kas Operasi, Dan Investment Opportunity Set (IOS) Terhadap Kebijakan Dividen (Studi Pada Perusahaan Badan Usaha Milik Negara yang Tercatat di BEI Periode 2011-2015). e-Proceeding of Managemen, 4(2), 15651571. 
Purnami, A., D., K., \& Artini, L. G. S. (2016). Pengaruh Investment Opportunity Set, Total Asset Turn Over dan Sales Growth Terhadap Kebijakan Dividen. E-Jurnal Manajemen Universitas Udayana, 5(2), 1309-1337.

Rehman, A., \& Takumi, H. (2012). Determinants of dividend payout ratio: Evidence from Karachi Stock Exchange (KSE). Journal of Contemporary Issues in Business Research, 1(1), 20-27.

Rudianto. (2018). Akuntansi Intermediate. Jakarta: Erlangga.

Samsul, M. (2015). Pasar Modal dan Manajemen Portofolio. Edisi 2. Jakarta: Erlangga.

Siregar, S. R., \& Hasanah, U. (2019). Pengaruh Laba Bersih dan Arus Kas Operasi terhadap Dividen Kas. JASa (Jurnal Akuntansi, Audit dan Sistem Informasi Akuntansi), 3(1), 63-72.

Steven, YAP. (2018). Pengaruh Investment Opportunity, Financing Company, Profitability, Cash and Market to Book Value Terhadap Dividend Payment Policy Pada Perusahaan Makanan Dan Minuman. Media Bisnis, 8(1), 13-21. https://doi.org/10.34208/mb.v8i1.349

Supeni, E. (2021). Pengaruh Profitabilitas, Invesment Opportunity Set Dan Cost Politic Terhadap Kebijakan Deviden Tunai Dengan Likuiditas Sebagai Variabel Moderasi Pada Perusahaan Plat Merah Yang Terdaftar Pada Bursa Efek Indonesia. Journal Of Applied Managerial Accounting, 5(1), 81-100. https://doi.org/10.30871/jama.v5i1.2776

Warren, C. S., Reeve, J. M., Duchac, J. E., Wahyuni, E. T., \& Jusuf, A. A. (2018). Pengantar Akuntansi 2 Adaptasi Indonesia. Edisi 4. Jakarta: Salemba Empat.

Wenas, D. D., Manossoh, H., \& Tirayoh, V. Z. (2017). Analisis Pengaruh Arus Kas Operasi dan Laba Bersih Terhadap Dividen Kas pada Perusahaan Properti yang Terdaftar di Bursa Efek Indonesia (BEI). Jurnal EMBA: Jurnal Riset Ekonomi, Manajemen, Bisnis dan Akuntansi, 5(1), 96-104.

Wijaya, T. W., Situmorang, M., \& Endah, R. M. (2016). Pengaruh Laba Bersih, Arus Kas Dan Nilai Perusahaan Terhadap Kebijakan Dividen Pada Perusahaan Sub Sektor Konstruksi dan Bangunan yang Terdaftar di Bursa Efek Indonesia Periode 2012-2015. Jurnal Online Mahasiswa (JOM) Bidang Akuntansi, 2(2). 
Rochman Marota: Kebijakan Pembagian Dividen ... 